\title{
Silver nanoparticles of Albizia adianthifolia: the induction of apoptosis in human lung carcinoma cell line
}

\author{
Rishalan Govender ${ }^{1}$, Alisa Phulukdaree ${ }^{1}$, Robert M Gengan², Krishnan Anand ${ }^{2}$ and Anil A Chuturgoon ${ }^{\text {* }}$
}

\begin{abstract}
Background: Silver nanoparticles (AgNP), the most popular nano-compounds, possess unique properties. Albizia adianthifolia (AA) is a plant of the Fabaceae family that is rich in saponins. The biological properties of a novel AgNP, synthesized from an aqueous leaf extract of $A A\left(A A_{A g N P}\right)$, were investigated on A549 lung cells. Cell viability was determined by the MTT assay. Cellular oxidative status (lipid peroxidation and glutathione (GSH) levels), ATP concentration, caspase-3/-7, -8 and -9 activities were determined. Apoptosis, mitochondrial (mt) membrane depolarization (flow cytometry) and DNA fragmentation (comet assay) were assessed. The expression of CD95 receptors, p53, bax, PARP-1 and smac/DIABLO was evaluated by flow cytometry and/or western blotting.

Results: Silver nanoparticles of AA caused a dose-dependent decrease in cell viability with a significant increase in lipid peroxidation (5-fold vs. control; $p=0.0098$ ) and decreased intracellular GSH ( $p=0.1184$ ). A significant 2.5-fold decrease in cellular ATP was observed upon $\mathrm{AA}_{\mathrm{AgNP}}$ exposure $(p=0.0040)$ with a highly significant elevation in $\mathrm{mt}$ depolarization (3.3-fold vs. control; $p<0.0001$ ). Apoptosis was also significantly higher $\left(1.5\right.$-fold) in $\mathrm{AA}_{\mathrm{AgNP}}$ treated cells $(p<0.0001)$ with a significant decline in expression of CD95 receptors $(p=0.0416)$. Silver nanoparticles of AA caused a significant 2.5-fold reduction in caspase-8 activity $(p=0.0024)$ with contrasting increases in caspase-3/-7 (1.7-fold vs. control; $p=0.0180$ ) and -9 activity (1.4-fold vs. control; $p=0.0117)$. Western blots showed increased expression of smac/DIABLO (4.1-fold) in treated cells $(p=0.0033)$. Furthermore, $\mathrm{AA}_{\mathrm{AgNP}}$ significantly increased the expression of $\mathrm{p} 53$, bax and PARP-1 (1.2-fold; $p=0.0498,1.6$-fold; $p=0.0083$ and 1.1-fold; $p=0.0359$ respectively).
\end{abstract}

Conclusion: Data suggests that $\mathrm{AA}_{\mathrm{AgNP}}$ induces cell death in the $\mathrm{A} 549$ lung cells via the mt mediated intrinsic apoptotic program. Further investigation is required to potentiate the use of this novel compound in cancer therapy trials.

Keywords: Nanosilver, Albizia adianthifolia, Cancer, Apoptosis, Smac/DIABLO

\section{Introduction}

Cancer is a leading cause of global morbidity and mortality [1]. In 2006 there were 4525 deaths due to lung cancer in South Africa [1]. As much as $80-90 \%$ of lung cancer cases are attributed to smoking, with the smaller proportion (10-20\%) as a result of occupational exposure to heavy metals $[2,3]$. Much recently, an association has been found between the acquired immunodeficiency syndrome (AIDS) and the development of lung cancer [4].

\footnotetext{
* Correspondence: chutur@ukzn.ac.za

'Discipline of Medical Biochemistry, School of Laboratory Medicine and Medical Sciences, University of KwaZulu-Natal, Private Bag 7, Congella, Durban 4013, South Africa

Full list of author information is available at the end of the article
}

This is of concern considering the crisis of AIDS in South Africa. The financial strain of anti-retroviral treatment and cancer therapy necessitates the need for alternate means of cancer treatment that is cost effective, easily accessible and safe.

Nanoparticles (NPs) are small sized (1-100 nm) compounds that are able to function as whole units. These compounds are becoming widespread for their use in consumer products and medical applications; with potential for utilization as therapeutic compounds, transfection vectors, anti-microbial agents and fluorescent labels [5]. Silver NPs are the most commercialized and prominent group of nano-compounds, attributed to their diverse applications in the health sector.

\section{Biomed Central}


Silver (Ag) possesses unique and unusual chemical, physical as well as biological properties [6]. Silver, in a colloidal form, is used for the treatment of bacterial infections in open wounds, and preparation of ointments, bandages and wound dressings [7]. Additionally, nanosilver has been used as a contraceptive, and marketed as a water disinfectant $[8,9]$.

Silver NPs are now being exploited for the treatment of various diseases such as retinal neurovascularization $[10,11]$ and acquired immunodeficiency syndrome as a result of human immunodeficiency virus [12]. Additionally, AgNPs are well known for their anti-microbial properties and are used as antiviral agents against hepatitis B, herpes simplex virus type 1 , monkey pox virus and respiratory syncytial virus $[13,14]$.

Concerns on environmental exposure to AgNPs have initiated toxicity studies. Silver NP-hydrogel induced DNA damage and the production of reactive oxygen species (ROS) in cultured HeLa cells [15]. A study using human lymphocytes revealed that AgNPs caused DNA damage and cell death [16]. Additionally, AgNPs induced oxidative stress and caused impairment of nuclear DNA in Swiss albino mice [16].

Recently, the use of AgNPs as anti-cancer agents has proved promising [6]. Various attempts to incorporate AgNPs into cancer treatments have been made, with positive outcomes [17]. Although the induction of oxidative stress by AgNP induced $m t$ damage has been observed as the general mode of AgNP toxicity, mechanistic pathways remain unclear [18].

Albizia adianthifolia, a plant member of the Fabaceae family found abundantly on the east coast of South Africa, contains saponins such as prosapogenins and triterpene saponins $[19,20]$. Saponins are plant glycosides that were found to induce cell cycle arrest in a human breast cancer cell line and initiation of apoptosis in a leukemia cell line [21]. Additionally, certain classes of saponins can sequester serum cholesterol and modulate the immune response [22]. The individual properties of $\mathrm{Ag}$ and AA were considered for the synthesis of a novel AgNP using aqueous leaf extracts of the plant.

The A549 cell line (human lung carcinoma) is well characterized and extensively used in in vitro nanotoxocity studies [23]. A recent study postulated that the induction of ROS and alterations in $\mathrm{mt}$ membrane permeability were possible mechanisms by which AgNP exerted its toxic effects in A549 cells [24]. The aim of this study was to investigate the effects of $\mathrm{AA}_{\mathrm{AgNP}}$ on lung cancer cells. It was hypothesized that $\mathrm{AA}_{\mathrm{AgNP}}$ induced cell death by apoptosis as a result of $\mathrm{AA}_{\mathrm{AgNP}}$ mediated generation of ROS. We report on a possible mechanism by which $\mathrm{AA}_{\mathrm{AgNP}}$ induced apoptosis in the A549 cells.

\section{Results}

\section{Cell viability assay}

Toxicity of $\mathrm{AA}_{\mathrm{AgNP}}$ to A549 cells was determined using the MTT assay. A dose-dependent decline in cell viability was observed using $\mathrm{AA}_{\mathrm{AgNP}}$ concentrations in the range 0 to $75 \mu \mathrm{g} / \mathrm{ml}$ for $6 \mathrm{~h}(95 \% \mathrm{Cl}=31.96$ to 57.72$)$ (Figure 1$)$. An $\mathrm{IC}_{50}$ value of $43 \mu \mathrm{g} / \mathrm{ml}$ was obtained and used in all subsequent assays.

\section{ATP analysis}

Levels of ATP were assessed using luminometric assay. Silver nanoparticles of AA significantly reduced ATP levels with a 2.5 -fold decrease $(350,000 \pm 1500$ RLU; $95 \%$ $\mathrm{CL}=330,000$ to 370,000$)$ compared to the control $(990,000 \pm 40,000 \mathrm{RLU} ; 95 \% \mathrm{Cl}=480,000$ to $1,500,000$; $p=0.0040$ ) (Figure 2).

\section{Oxidative status}

Glutathione concentrations were measured as a marker for intracellular anti-oxidant capacity. The concentration of GSH was higher in untreated cells $(15 \pm 1.3 \mu \mathrm{M})$ compared to $\mathrm{AA}_{\mathrm{AgNP}}$ treated cells $(12 \pm 0.24 \mu \mathrm{M}, 95 \%$ $\mathrm{Cl}=-1.0$ to $6.2 ; p=0.1184$ ) (Figure $3 \mathrm{~A}$ ). Lipid peroxidation (MDA) was significantly 5-fold higher in cells exposed to $\mathrm{AA}_{\mathrm{AgNP}}(0.16 \pm 0.023 \mu \mathrm{M})$ compared to controls $(0.032 \pm 0.016 \mu \mathrm{M}, 95 \% \mathrm{Cl}=-0.21$ to $-0.049 ; p=0.0098)$ (Figure 3B).

\section{Analysis of caspases}

$\mathrm{AA}_{\mathrm{AgNP}}$ significantly increased the activities of caspase-3/-7 (1.7-fold, 95\% Cl=-1,000,000 to $-260,000 ; p=0.0180$ )

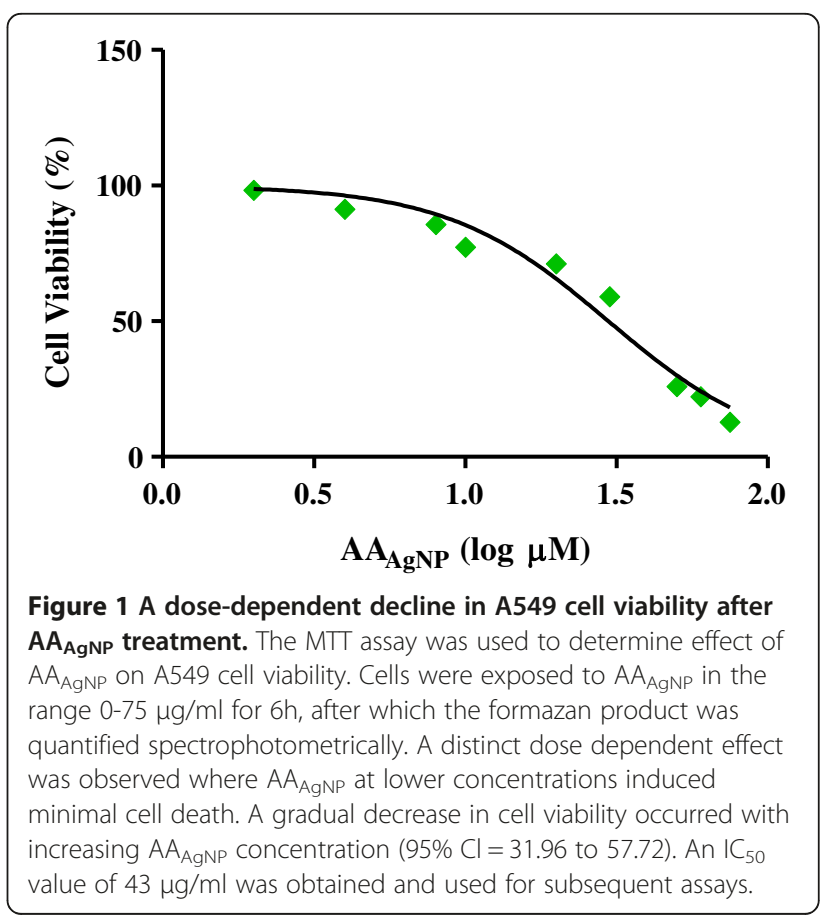




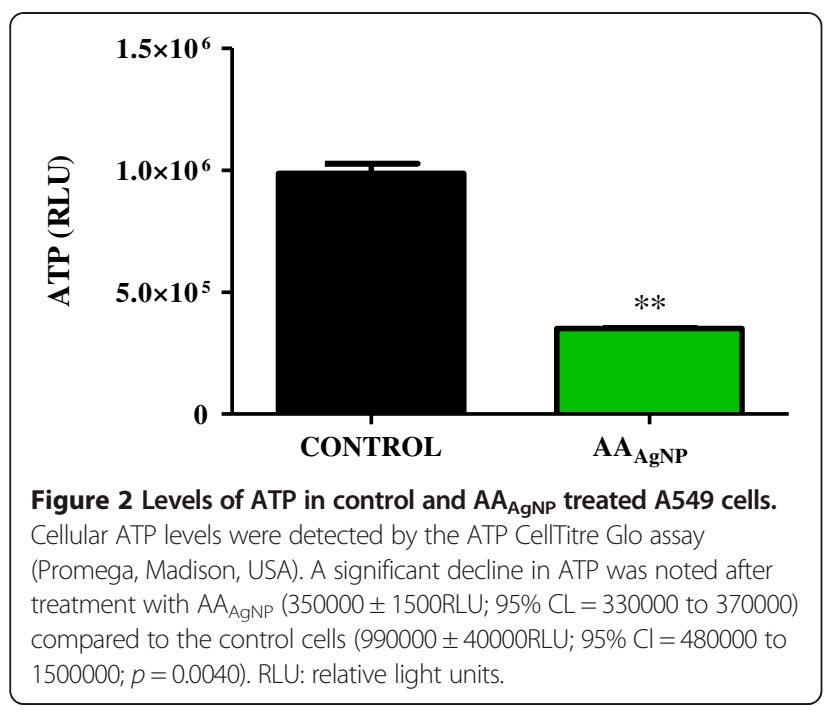

and -9 (1.4-fold, 95\% $\mathrm{Cl}=-610,000$ to $-220,000 ; p=$ 0.0117 ) compared to the control. The activity of caspase- 8 however was significantly decreased by $\mathrm{AA}_{\mathrm{AgNP}}$ compared to untreated cells (2.5-fold, $95 \% \mathrm{Cl}=550,000$ to 840,000 ; $p=0.0024)$ (Table 1$)$.

\section{Flow cytometry}

Silver nanoparticles of AA significantly increased PS translocation A549 cell compared to the control ( $57 \pm 0.59 \%$ vs. $10 \pm 0.84 \%, 95 \% \mathrm{Cl}=-50$ to $-43 ; p<0.0001$ ) (Figure $4 \mathrm{~A}$ ). Additionally, the percentage of necrotic cells were also significantly higher in $\mathrm{AA}_{\mathrm{AgNP}}$ treated cells $(17 \pm 0.79 \%$ vs. control: $4.6 \pm 0.70 \%, 95 \% \mathrm{Cl}=-16$ to $-9.2 ; p<0.0001)$ (Figure $4 \mathrm{~A}$ ). The apoptosis inducing potential of $\mathrm{AA}_{\mathrm{AgNP}}$ was further verified in disrupting mt $\Delta \Psi$. The treated cells had significantly higher $\mathrm{mt}$ depolarization compared to untreated cells ( $77 \pm 0.88 \%$ vs. $23 \pm 1.8 \%, 95 \% \mathrm{Cl}=44$ to 57 ; $p<0.0001$ ) (Figure 4B).

The expression of CD95 was significantly down regulated (2-fold; $2.8 \pm 0.58 \%$ vs. control: $5 \pm 0.44 \%, 95 \% \mathrm{Cl}=0.13$ to $4.2 ; p=0.0416$ ) (Table 2). In contrast, $\mathrm{AA}_{\mathrm{AgNP}}$ significantly increased the expression of smac/DIABLO, a pro-apoptotic protein $(29 \pm 0.32 \%)$ compared to the control $(18 \pm 0.66 \%$, $95 \% \mathrm{Cl}=-13$ to $-8.5 ; p<0.0001$ ) (Table 2). Additional files contain the histograms for extra- and intracellular staining (see Additional file 1: Figure S1 and Additional file 2: Figure S2 respectively).

\section{Comet assay}

Silver nanoparticles of AA were significantly genotoxic to A549 cells as noted by the increased DNA fragmentation. Comet tail lengths were significantly longer in treated $(90 \pm 1.3 \mu \mathrm{m})$ compared to untreated cells $(20 \pm 0.71 \mu \mathrm{m}$, $95 \% \mathrm{Cl}=-73$ to $-67 ; p<0.0001$ ) (Figure 5).

\section{Western blot analysis}

The expression of selected apoptotic proteins and validation of flow cytometric intracellular stained smac/DIABLO was determined by western blotting. The expression of p53 was observed to be significantly higher post $\mathrm{AA}_{\mathrm{AgNP}}$ exposure $(1.0 \pm 0.018 \mathrm{RBI}$ vs. control: $0.82 \pm 0.045 \mathrm{RBI}, 95 \% \mathrm{Cl}=-0.42$ to $-0.00037 ; p=0.0498)$. A significant increase in the $24 \mathrm{kDa}$ fragment of PARP-1 was noted after $\mathrm{AA}_{\mathrm{AgNP}}$ treatment $(3.5 \pm 0.069 \mathrm{RBI}$ vs. control: $3.1 \pm 0.0043 \mathrm{RBI}, 95 \% \mathrm{Cl}=-0.65$ to $-0.058 ; p=0.0359)$. Evaluation of bax showed higher levels of the protein in cells that were treated with $\mathrm{AA}_{\mathrm{AgNP}}(3.4 \pm 0.11 \mathrm{RBI})$ compared to untreated cells $(2.1 \pm 0.047 \mathrm{RBI}, 95 \% \mathrm{Cl}=-1.9$ to $-0.81 ; p=0.0083)$. Highly significant differences were seen in the expression of smac/DIABLO between experimental and control cells. Silver nanoparticles of AA treated cells presented with a 4.1 -fold greater band intensity $(1.1 \pm 0.045 \mathrm{RBI}$ vs. control: $0.27 \pm 0.010 \mathrm{RBI}, 95 \% \mathrm{Cl}=-0.99$ to $-0.59 ; p=0.0033$ ) (Figure 6).

\section{Discussion}

Several pathological syndromes such as liver failure, stroke or heart attack are associated with abrupt death of tissue or organs as a result of apoptotic dysregulation. Conversely, the survival of abnormal cells, due to aberrant
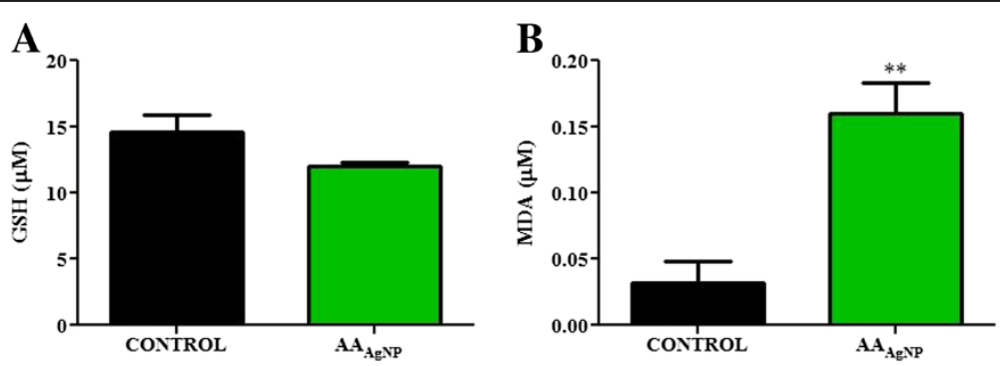

Figure 3 A) Levels of GSH and B) MDA (lipid peroxidation) in $\mathbf{A A}_{\mathrm{AgNP}}$ treated and untreated cells. The oxidative status of A549 cells were assessed by quantifying GSH and MDA. Levels of the anti-oxidant GSH were measured by the GSH-Glo ${ }^{\text {TM }}$ Glutatione assay (Promega, Madison, USA). $\mathrm{AA}_{\mathrm{AgN}}$ caused a decrease in GSH $(12 \pm 0.24 \mu \mathrm{M})$ compared to untreated cells $(15 \pm 1.3 \mu \mathrm{M}, 95 \% \mathrm{Cl}=-1.0$ to $6.2 ; p=0.1184)$. The TBARS assay was utilized to quantify MDA levels as marker for lipid peroxidation induced by ROS. A significant elevation in MDA levels were found in cells exposed to $\mathrm{AA}_{\mathrm{AgNP}}(0.16 \pm 0.023 \mu \mathrm{M})$ compared to the control $(0.032 \pm 0.016 \mu \mathrm{M}, 95 \% \mathrm{Cl}=-0.21$ to $-0.049 ; p=0.0098)$. 
Table 1 Caspase activity in $\mathrm{AA}_{\mathrm{AgNP}}$ treated cells

\begin{tabular}{|c|c|c|c|}
\hline & \multirow{2}{*}{$\begin{array}{l}\text { Control } \\
\text { Mean RLU } \pm \text { sem }\end{array}$} & \multicolumn{2}{|l|}{$\mathrm{AA}_{\mathrm{AgNP}}$} \\
\hline & & Mean RLU \pm sem & $p$ value \\
\hline CASPASE-8 & $1.2 \times 10^{6} \pm 2.6 \times 10^{4}$ & $4.6 \times 10^{5} \pm 2.3 \times 10^{4}$ & $0.0024^{* *}$ \\
\hline CASPASE-9 & $9.2 \times 10^{5} \pm 3.3 \times 10^{4}$ & $1.3 \times 10^{6} \pm 3.1 \times 10^{4}$ & $0.0117^{*}$ \\
\hline CASPASE-3/-7 & $9.2 \times 10^{5} \pm 4 \times 10^{3}$ & $1.6 \times 10^{6} \pm 8.6 \times 10^{4}$ & $0.0180^{*}$ \\
\hline
\end{tabular}

RLU: relative light units.

apoptosis, may lead to tumorigenesis [25]. Apoptosis is commonly altered in cancerous cells, which have the ability to evade the apoptotic cascade.

Silver nanoparticles of AA significantly increased PS externalization, a transmembrane glycoprotein, in the treated A549 cells (Figure 4A).

The signal transduction of apoptosis involves a cascade of initiator and executioner caspases [26]. Executioner caspases-3/-7 cleave specific substrates leading to alteration changes linked with apoptosis and ultimately cell death [27]. Initiator caspses-8 and -9 are responsible for the activation of executioner caspases. Silver nanoparticles of AA significantly up regulated the activities of caspases-3/-7 and -9 (Table 1). Furthermore $\mathrm{AA}_{\mathrm{AgNP}}$ increased DNA fragmentation (Figure 5)-an end stage characteristic of apoptosis. In response to this DNA damage, the nuclear enzyme PARP-1 catalyzes the transfer of $\mathrm{NAD}^{+}$to a specific set of nuclear substrates [28]. During apoptosis, PARP-1 is cleaved, by executioner caspases-3/-7, to a $24 \mathrm{kDa}$ DNA binding domain and an $89 \mathrm{kDa}$ fragment containing catalytic activity. Silver nanoparticles of AA was responsible for the cleavage of PARP-1 as evidenced by the significantly increased expression of $24 \mathrm{kDa}$ fragment compared to untreated control cells (Figure 6B).

Mitochondria play an important role in apoptosis, via the intrinsic apoptotic program. An initial step for activation of the intrinsic apoptotic pathway is the depolarization of the $\mathrm{mt}$ membrane. Depolarized $\mathrm{mt}$ is as a result of the formation of $\mathrm{mt}$ permeability transition (PT) pores [29]. Mitochondrial PT has been associated with various metabolic consequences such as halted functioning of the electron transport chain with associated elevation in ROS and decreased production of ATP [30]. Bax, a pro-apoptotic protein of the Bcl-2 family, translocates from the cytosol to the outer $\mathrm{mt}$ membrane during apoptosis where it interacts with lipids and induces mt PT pores. A significant increase in mt depolarization was observed after $\mathrm{AA}_{\mathrm{AgNP}}$ treatment (Figure 4B), with an accompanying decrease in ATP concentration (Figure 2). The high levels of bax expression (Figure 6C), high $\mathrm{mt}$ depolarization and decreased ATP suggest that $\mathrm{AA}_{\mathrm{AgNP}}$ induces cellular apoptosis in cancerous lung cells via the intrinsic apoptotic pathway.

Silver has a high affinity for thiol (-SH) groups [31]. In this study, the levels of cysteine-rich GSH were decreased whilst lipid peroxidation was significantly elevated by $\mathrm{AA}_{\mathrm{AgNP}}$ (Figure 3 ). This oxidant/anti-oxidant imbalance has previously been documented as an apoptotic mechanism by AgNP mediated cytotoxicity [32,33].

The extrinsic apoptotic pathway is mediated by CD95 death receptor, which recruits Fas-associated protein with death domain (FADD) adapter protein. The adapter protein FADD binds to and activates caspase- 8 via the formation of a death-inducing signaling complex [25]. The results of this study show that CD95 expression (Table 2) and caspase- 8 activity (Table 1 ) was significantly decreased by $\mathrm{AA}_{\mathrm{AgNP}}$. The extracts of $\mathrm{AA}$ are rich in saponins, which will promote rapid entry of the $\mathrm{AA}_{\mathrm{AgNP}}$ into the cells resulting in $\mathrm{mt}$ mediated intrinsic apoptotic pathway. A well characterized biological action of saponins is their ability to induce cell membrane permeabilization [34]. Decreased ATP concentrations and increased MDA as a result of ROS may be due to disruptions in the $\mathrm{mt}$ respiratory chain. Nanoparticles preferentially localize in $\mathrm{mt}$ and cause oxidative stress as
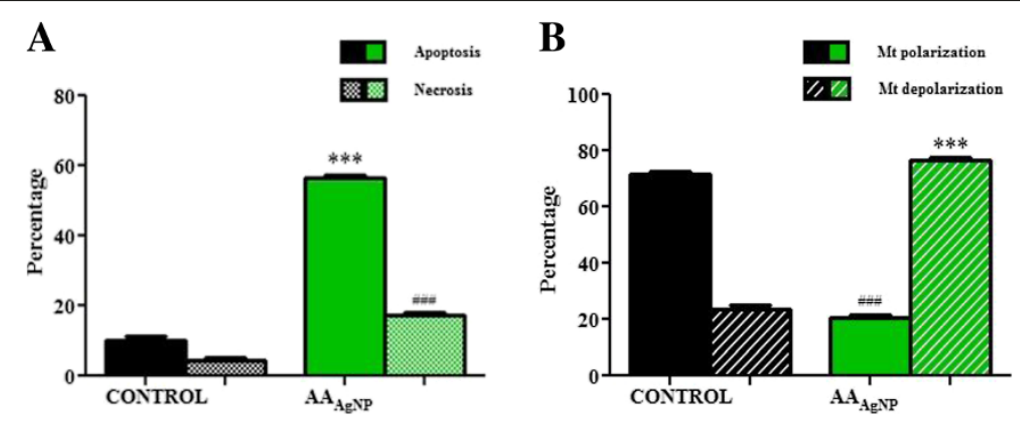

Figure 4 A) Percentages of apoptotic and necrotic cells and B) Mt depolarization after treatment with $\mathrm{AA}_{\mathrm{AgNP}}$. Flow cytometry was used to examine PS translocation (annexin-V-Fluos assay (Roche)) and mt membrane integrity (BD ${ }^{\mathrm{TM}}$ MitoScreen kit (BD Biosciences). A significant increase in apoptosis ( $57 \pm 0.59 \%$ vs. control: $10 \pm 0.84 \%, 95 \% \mathrm{Cl}=-50$ to $-43 ; p<0.0001)$ and necrosis ( $17 \pm 0.79 \%$ vs. control: $4.6 \pm 0.70 \%, 95 \% \mathrm{Cl}=-16$ to -9.2 ; $p<0.0001)$ following treatment was seen. Furthermore, $\mathrm{mt}$ membrane depolarization was significantly higher in $\mathrm{AA}_{\text {AgNP }}$ treated cells $(77 \pm 0.88 \%$ vs. control: $23 \pm 1.8 \%, 95 \% \mathrm{Cl}=44$ to $57 ; p<0.0001)$. 
Table 2 Surface expression of CD95 and intracellular smac/DIABLO in A549 cells treated with $\mathrm{AA}_{\mathrm{AgNP}}$ as determined flow cytometrically

\begin{tabular}{llll}
\hline & $\begin{array}{l}\text { Control } \\
\text { Mean } \% \pm \text { sem }\end{array}$ & $\begin{array}{l}\mathbf{A A}_{\text {AgNP }} \\
\text { Mean } \% \pm \text { sem }\end{array}$ & $\boldsymbol{p}$ value \\
\hline FITC + ve (CD95) & $5 \pm 0.44$ & $2.8 \pm 0.58$ & $0.0416^{*}$ \\
$\begin{array}{l}\text { APC + ve } \\
\text { (smac/DIABLO) }\end{array}$ & $18 \pm 0.66$ & $29 \pm 0.32$ & $<0.0001^{* * *}$ \\
\hline
\end{tabular}

well as potentiate structural damage $[35,36]$. Various studies have associated AgNP toxicity with mt damage $[37,38]$.

Several pro-apoptotic molecules are released from the mt during apoptosis. In the presence of ATP, mt released cytochrome $\mathrm{c}$ associates with apoptotic protease-activating factor (Apaf)-1 in the cytosol inducing its oligomerization. An apoptosome is then formed with the oligomeric Apaf-1 complex and procaspase-9, inducing the activation of caspase-9, which in turn activates effector caspases-3 and -7 [26]. An interesting finding in this study was that although ATP levels were reduced post $\mathrm{AA}_{\mathrm{AgNP}}$ treatment, the activity of caspase- 9 was still elevated (Table 1).

A class of molecules involved in the regulation of apoptosis is the inhibitor of apoptosis (IAP) proteins. These proteins avert cell death by suppressing the activity of caspases. X-chromosome-linked inhibitor of apoptosis (XIAP) is the most well characterized member of IAPs [25]. The ability of IAPs to act as endogenous suppressors of procaspase activation is attributed to the presence of domains referred to as baculoviral IAP repeats (BIR).

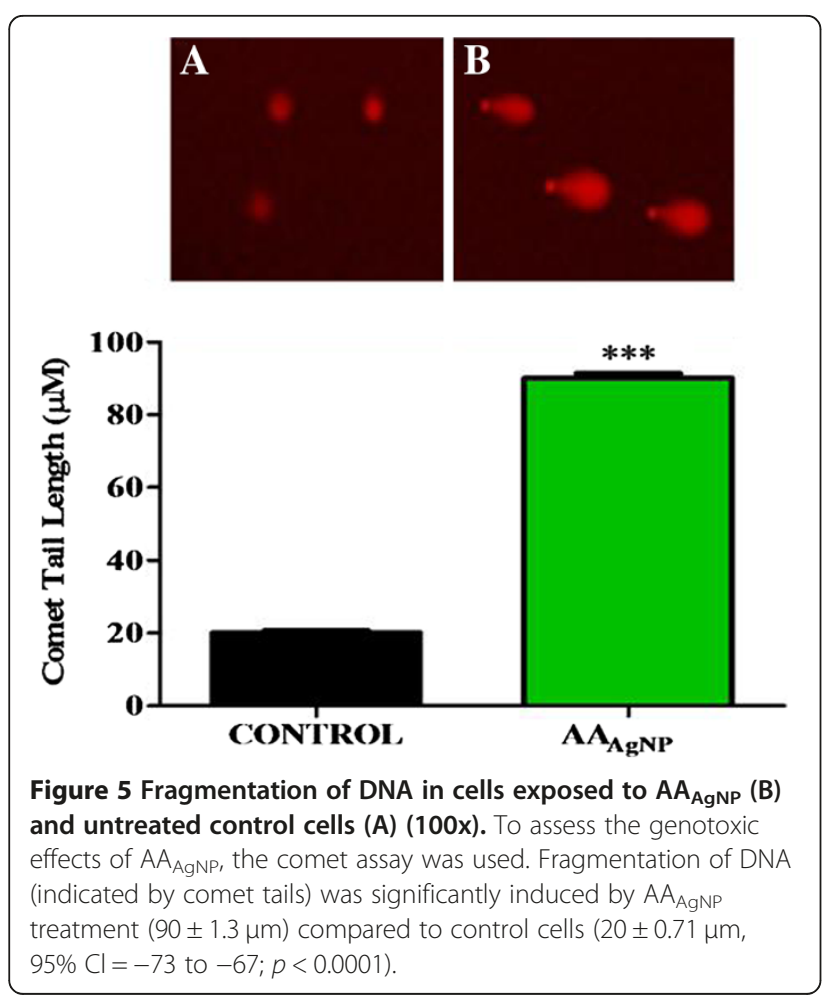

In particular, BIR3 and a region adjacent to BIR2 are responsible for the inhibition of caspases-9, and -3 and -7 respectively. Smac/DIABLO, a mt protein, is able to abolish the inhibitory effects of XIAP [26]. Both smac/ DIABLO and caspases-3,-7 and -9 contain IAP-binding motifs that fit into the BIR domains of XIAP. Thus, smac/ DIABLO is able to relieve inhibition by replacing and releasing caspases-3, -7 and -9 from the XIAP inhibitory complex $[25,26]$. We postulated that $\mathrm{AA}_{\mathrm{AgNP}}$ released smac/DIABLO from the mt. The increased intracellular staining (Table 2) and expression of smac/DIABLO by western blotting (Figure 6D) confirmed that $\mathrm{AA}_{\mathrm{AgNP}}$ induced its release from the $\mathrm{mt}$.

The p53 protein mediates a range of anti-proliferative processes in response to different stress stimuli by directly activating apoptosis and promoting the release of bax [39] and inducing executioner caspase activity [40] Also, p53 interferes with $\mathrm{mt}$ integrity and function leading to the release of pro-apoptotic molecules and the generation of ROS [41]. This study clearly shows the increased expression of p53 after addition of $\mathrm{AA}_{\mathrm{AgNP}}$ to cells (Figure 6A).

\section{Conclusion}

In conclusion, this novel $\mathrm{AA}_{\mathrm{AgNP}}$ possesses potent proapoptotic potential. We have shown, mechanistically, that $\mathrm{AA}_{\mathrm{AgNP}}$ activates the intrinsic apoptotic pathway in A549 lung carcinoma cells. The findings of this study suggest the potential for $\mathrm{AA}_{\mathrm{AgNP}}$ in drug development against cancer. None the less, further studies need to be conducted to ascertain if the effects of $\mathrm{AA}_{\mathrm{AgNP}}$ are consistent in other cancerous cell lines and also non-toxic to healthy systems.

\section{Materials and methods Materials}

A549 cells were purchased from Highveld Biologicals (Johannesburg, South Africa). Cell culture reagents were purchased from Whitehead Scientific (Johannesburg, South Africa). LumiGLO ${ }^{\circledR}$ chemiluminescent substrate kit was purchased from Gaithersburg (USA) and western blot reagents were purchased from Bio-Rad (USA). All other reagents were purchased from Merck (South Africa).

\section{Synthesis of $\mathrm{AA}_{\mathrm{AgNP}}$}

Synthesis and characterization of $\mathrm{AA}_{\mathrm{AgNB}}$ described by Gengan et al. 2013, was conducted at the Steve Biko campus, Durban University of Technology, Durban, South Africa. A one-pot green synthesis technique was used [42]. Briefly, fresh leaves of AA were extracted with deionized water. The crude extract was filtered and the supernatant was allowed to react with silver nitrate solution at room temperature (RT). Silver nanoparticles of AA solution $(\mathrm{pH}$ 7) were then characterized using UV spectrometry. Particle size was determined by transmission electron microscopy. To assess the interaction between nanosilver 

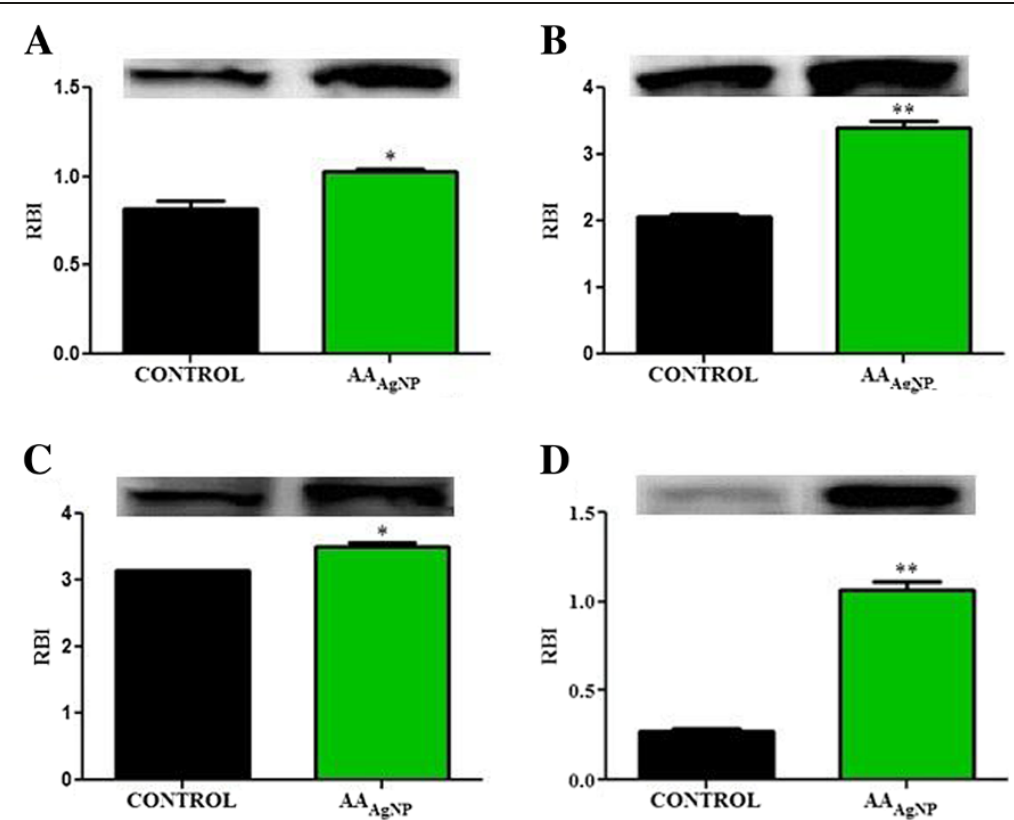

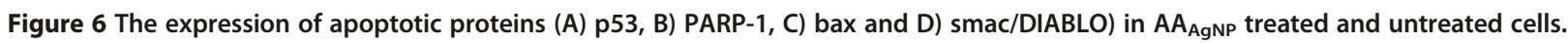
Western blotting assessed the expression of selected apoptotic proteins. Levels of p53 were significantly higher post $\mathrm{AA}_{\mathrm{AgNP}}$ exposure $(1.0 \pm 0.018 R B I$ vs. control: $0.82 \pm 0.045 \mathrm{RBI}, 95 \% \mathrm{Cl}=-0.42$ to $-0.00037 ; p=0.0498)$. Cleavage of PARP- 1 was distinct with significant increase in the 24kDa fragment after $\mathrm{AA}_{\mathrm{AgNP}}$ treatment $(3.5 \pm 0.069 \mathrm{RBI}$ vs. control: $3.1 \pm 0.0043 \mathrm{RBI}, 95 \% \mathrm{Cl}=-0.65$ to $-0.058 ; p=0.0359)$. The expression of bax was significantly higher in cells that were treated with $\mathrm{AA}_{\mathrm{AgNP}}(3.4 \pm 0.11 \mathrm{RBI})$ compared to untreated cells $(2.1 \pm 0.047 \mathrm{RBI}, 95 \% \mathrm{Cl}=-1.9$ to -0.81 ; $p=0.0083)$. $\mathrm{AA}_{\mathrm{AgNP}}$ treated cells presented with a 4.1 -fold greater band intensity for smac/DIABLO $(1.1 \pm 0.045 \mathrm{RBI}$ vs. control: $0.27 \pm 0.010 \mathrm{RBI}$, $95 \% \mathrm{Cl}=-0.99$ to $-0.59 ; p=0.0033)$. Protein bands were standardized against $\beta$-actin.

and compounds of the aqueous extracts of AA leaves, Fourier transform infrared spectrophotometry was employed [42]. Ethical approval from the Biomedical Research Ethics Administration Office of the University of KwaZuluNatal (Reference number: BE050/08) was obtained.

\section{Cell culture and exposure protocol}

The A549 cells were cultured in Eagle's minimum essential medium supplemented with $1 \%$ L-glutamine, $1 \%$ penstrepfungizone and $10 \%$ fetal bovine serum. Cultures were maintained at $37^{\circ} \mathrm{C}$ with $5 \% \mathrm{CO}_{2}$. For the $3-(4,5-$ Dimethyl-2-thiazolyl)-2,5-diphenyl-2H-tetrazolium bromide (MTT) assay, cells were seeded into a 96-well microtitre plate, allowed to attach overnight and treated with $\mathrm{AA}_{\mathrm{AgNP}}$ solution $(0-75 \mu \mathrm{g} / \mathrm{ml})$. For flow cytometry assays, caspase, ATP and lipid peroxidation assays, cells were cultured to $90 \%$ confluency in $25 \mathrm{~cm}^{2}$ tissue flasks and treated with $\mathrm{AA}_{\mathrm{AgNP}}$. For the GSH assay, cells were plated in 96-well microtitre plates and allowed to attach overnight, followed by treatment with $\mathrm{AA}_{\mathrm{AgNP}}$. For western blot analysis and the comet assay, cells were grown to $90 \%$ confluency in 6-well culture plates and treated with $\mathrm{AA}_{\mathrm{AgNP}}$.

\section{Cell viability assay}

Cell viability was determined using the MTT assay. Approximately 20,000 cells (in six replicates) were used for exposure to $\mathrm{AA}_{\mathrm{AgNP}}$ concentrations in the treatment range. After incubation with $\mathrm{AA}_{\mathrm{AgNP}}$ for $6 \mathrm{~h}$, cells were washed twice with $0.1 \mathrm{M}$ phosphate buffer saline (PBS) and incubated with MTT salt solution $(5 \mathrm{mg} / \mathrm{ml}$ in $0.1 \mathrm{M}$ PBS) and complete culture medium $\left(37^{\circ} \mathrm{C}, 4 \mathrm{~h}\right)$. Thereafter, $100 \mu \mathrm{l}$ of dimethyl sulfoxide was added to each well and incubated $\left(37^{\circ} \mathrm{C}, 1 \mathrm{~h}\right)$. Optical density of the formazan product was measured using a spectrophotometer (Bio-tek $\mu$ Quant) at $570 / 690 \mathrm{~nm}$. The results were expressed as percentage cell viability vs. concentration of $\mathrm{AA}_{\mathrm{AgNP}}$ from which the half maximal inhibitory concentration $\left(\mathrm{IC}_{50}\right)$ was determined.

\section{ATP assay}

Cells (20,000/well in six replicates) were aliquoted in an opaque 96-well microtitre plate to which the ATP CellTitre Glo (Promega, Madison, USA) reagent (50 $\mu \mathrm{l})$ was added and allowed to react in the dark ( $30 \mathrm{~min}, \mathrm{RT}$ ). After incubation, the luminescent signal proportional to the cellular ATP content was detected with a Modulus ${ }^{\text {TM }}$ microplate reader (Turner Biosystems, Sunnyvale, USA). The results were expressed as mean relative light units (RLU).

\section{Glutathione assay}

The GSH-Glo ${ }^{\mathrm{TM}}$ Glutatione assay (Promega, Madison, USA) was utilized to quantify intracellular GSH levels. Subsequent 
to treatment of cells $(10,000$ cells/well in six replicates) in an opaque 96-well microtitre plate, culture medium was removed and $25 \mu \mathrm{l}$ of $1 \mathrm{X} \mathrm{GSH}-\mathrm{Glo}^{\mathrm{TM}}$ reagent (prepared according to manufacturer's guidelines) was added to each well. Glutathione standards (0-5M) were serially diluted (two-fold) from a $5 \mathrm{mM}$ stock in deionized water. After brief mixing on a shaker and 30 min incubation at RT, $100 \mu \mathrm{l}$ of Luciferin detection reagent was added to the wells (15 min, RT). Luminescence was detected on a Modulus $^{\mathrm{TM}}$ microplate luminometer (Turner Biosystems, Sunnyvale, USA). A calibration curve was constructed and sample GSH concentrations $(\mu \mathrm{M})$ were calculated.

\section{Lipid peroxidation}

To investigate the $\mathrm{AA}_{\mathrm{AgNP}}$-mediated generation of reactive oxygen species (ROS), malondialdehyde (MDA-a product of lipid peroxidation) levels were measured using the thiobarbituric acid reactive substances (TBARS) assay. Briefly, the following was added to a set of test tubes: $200 \mu \mathrm{l}$ of $2 \% \mathrm{H}_{3} \mathrm{PO}_{4}, 400 \mu \mathrm{l}$ of $7 \% \mathrm{H}_{3} \mathrm{PO}_{4}, 400 \mu \mathrm{l}$ of TBA/ BHT solution and $200 \mu \mathrm{l}$ of $1 \mathrm{M}$ HCL. Following treatment of cells $(50,000$ cells/well) in a 6-well plate, supernatants were recovered. For test samples, $100 \mu \mathrm{l}$ of cell supernatant (in triplicate) was then added to each test tube. A positive control was prepared by adding $1 \mu \mathrm{l}$ of MDA to a test tube. All tubes were incubated in a water bath $\left(100^{\circ} \mathrm{C}, 15 \mathrm{~min}\right)$ and after cooling; butanol ( $1.5 \mathrm{ml})$ was added to each tube, vortexed for 10 seconds and allowed to separate into two distinct phases. Approximately $800 \mu \mathrm{l}$ of the upper butanol phase was then transferred to $1.5 \mathrm{ml}$ tubes and centrifuged ( $\left.840 \mathrm{x} \mathrm{g}, 24^{\circ} \mathrm{C} ; 6 \mathrm{~min}\right)$. To a 96 -well micotitre plate, $100 \mu \mathrm{l}$ of supernatant was transferred in six replicates and the absorbance read using a spectrophotometer (Bio-tek $\mu$ Quant) at $532 / 600 \mathrm{~nm}$. The mean absorbance was divided by the extinction co-efficient $\left(156 \mathrm{mM}^{-1}\right)$ and results were expressed as $\mu \mathrm{M}$ concentrations.

\section{Assessment of caspase activity}

Caspase-3/-7, -8 and -9 activities were detected with Caspase-Glo $^{\circledR}$ assays (Promega, Madison, USA). As per manufacturer's protocol, Caspase-Glo ${ }^{\circledR}-3 /-7,-8$ and -9 reagents were reconstituted and added to wells (in six replicates) of an opaque 96-well microtitre plate (40 $\mu \mathrm{l}$ of reagent per $100 \mu \mathrm{l}$ of 10,000 cells/well). Samples were mixed and incubated in the dark (30 min, RT). The luminescent signal was measured on a Modulus ${ }^{\text {TM }}$ microplate luminometer (Turner Biosystems, Sunnyvale, USA). Caspase-3/-7, -8 and -9 activities were expressed as relative light units (RLU).

\section{Annexin-V-FLUOS assay}

The annexin-V-Fluos assay (Roche) was used to determine phosphatidylserine (PS) translocation. To each flow cytometry tube, $100 \mu \mathrm{l}$ of staining buffer, $100 \mu \mathrm{l}$ of
annexin-V-Fluos labeling solution (annexin-V: propidium iodide (PI): staining buffer (1:1:50 vol/vol/vol)) and $100 \mu \mathrm{l}$ of cell suspension was added, and incubated in the dark (15 min, RT). Samples were analyzed on a FACS Calibur (BD Biosciences) flow cytometer. Data were analyzed using CellQuest PRO v4.02 software (BD Biosciences). Cells were gated to exclude cellular debris using FlowJo v7.1 software (Tree Star, Inc). Approximately 50,000 events were analyzed for apoptotic (annexin-V + ve, PI -ve), necrotic (annexin-V + ve, PI + ve) and live cells (annexin$\mathrm{V}$-ve, PI -ve). The results were expressed as percentage of the total events.

\section{JC-1 MitoScreen assay}

Mitochondrial membrane potential $(\Delta \Psi)$ was assayed with the $\mathrm{BD}^{\mathrm{TM}}$ MitoScreen kit (BD Biosciences). JC-1, a cationic dye, is sensitive to $\Delta \Psi$ and accumulates in $\mathrm{mt}$ with polarized membranes. JC-1 working solution was prepared and $100 \mu \mathrm{l}$ added to each flow cytometry tube, followed by $100 \mu \mathrm{l}$ of cell suspension. Tubes were incubated at $37^{\circ} \mathrm{C}$ with $5 \% \mathrm{CO}_{2}$ for $15 \mathrm{~min}$, after which $100 \mu \mathrm{l}$ of JC-1 wash buffer was added. Approximately 50,000 events were analyzed for $\mathrm{mt}$ depolarization. A FACS Calibur flow cytometer was used and data were analyzed using CellQuest PRO v4.02 software. Cells were gated to exclude cellular debris using FlowJo v7.1 software. The results were expressed as percentage of the total events.

\section{Comet assay}

The comet assay was used to determine DNA fragmentation in the $\mathrm{AA}_{\mathrm{AgNP}}$ treated lung cells. Briefly, three slides per sample were prepared with a first layer containing $400 \mu \mathrm{l}$ of $1 \%$ low melting point agarose (LMPA, $37^{\circ} \mathrm{C}$ ), a second layer of $25 \mu \mathrm{l}$ of cells from each sample with $175 \mu \mathrm{l} 0.5 \%$ LMPA $\left(37^{\circ} \mathrm{C}\right)$ and a third layer containing $200 \mu \mathrm{l}$ of $1 \% \mathrm{LMPA}\left(37^{\circ} \mathrm{C}\right)$. Cover slips were removed and slides were subjected to lysis $\left(4^{\circ} \mathrm{C}, 1 \mathrm{hr}\right.$, protected from light) by being submerged in cells lysis buffer $(2.5 \mathrm{M} \mathrm{NaCl}, 100 \mathrm{mM}$ EDTA, 1\% Triton X-100, $10 \mathrm{mM}$ Tris ( $\mathrm{pH} \mathrm{10)}$ and 10\% DMSO). The slides were equilibrated in electrophoresis buffer $(300 \mathrm{mM} \mathrm{NaOH}$, $1 \mathrm{mM} \mathrm{Na} 2$ EDTA, pH 13; $20 \mathrm{~min}$ ) then electrophoresced (300 $\mathrm{mA}, 25 \mathrm{~V}, 35 \mathrm{~min}$ ) after which slides were washed three times (0.4M Tris, $\mathrm{pH} 7.4 ; 5 \mathrm{~min})$ and finally stained with $40 \mu \mathrm{l}$ ethidium bromide. Cover slips were placed onto slides and maintained overnight at $4^{\circ} \mathrm{C}$. Slides were viewed using a fluorescent microscope (Olympus IXSI inverted microscope $/ 510-560 \mathrm{~nm}$ excitation and $590 \mathrm{~nm}$ emission wavelengths). Images were captured and comet tails of 50 cells were measured using Life Science-Soft Imaging System (analySIS ${ }^{\circledR}$ v5). The results were expressed as mean tail length in $\mu \mathrm{m}$. 


\section{CD95 (Fas) analysis}

CD95 receptor expression was determined by cell surface staining on a flow cytometer. Briefly, $100 \mu \mathrm{l}$ of $0.1 \mathrm{M}$ PBS and $1 \mu \mathrm{l}$ of fluorescein isothiocyanate (FITC) conjugated mouse anti-human CD95 antibody (BD Pharmingen, 555673) was added to $100 \mu \mathrm{l}$ of cell suspension. Reaction mixture was incubated in the dark for $15 \mathrm{~min}$ at RT, thereafter run on a FACS Calibur. Data were analyzed using CellQuest PRO v4.02 software. Cells were gated to exclude cellular debris using FlowJo v7.1 software. The results were expressed as a percentage.

\section{Intracellular staining}

Intracellular levels of smac/DIABLO were assessed by flow cytometry. Cells were rendered permeable by incubation in Fix and Perm medium A (Caltag) (15 min in the dark), after which they were treated with Fix and Perm medium B (Caltag) containing monoclonal anti-smac/DIABLO primary antibody (smac/DIABLO, ab110291) (1:500; $30 \mathrm{~min}$, RT). After washing, cells were re-suspended in medium B containing allophycocyanin (APC) conjugated anti-mouse secondary antibody (Thermo Scientific, 31430) (1:100; $15 \mathrm{~min}, \mathrm{RT}$ ) protected from light. Cells were then washed, re-suspended in 0.1M PBS and run on a FACS Calibur. Data were analyzed using CellQuest PRO v4.02 software. Cells were gated to exclude cellular debris using FlowJo v7.1 software. The results were expressed as percentage.

\section{Western blot analysis}

Cytobuster $^{\mathrm{TM}}$ reagent (Novagen) supplemented with protease and phosphatase inhibitors (Roche, 05892791001 and 04906837001 respectively) was used for protein isolation. Cytobuster $(200 \mu \mathrm{l})$ was added to the cells $\left(4^{\circ} \mathrm{C}\right.$, $10 \mathrm{~min})$ and centrifuged $\left(180 \mathrm{x} \mathrm{g} ; 4^{\circ} \mathrm{C}, 10 \mathrm{~min}\right)$ to obtain a crude protein extract. Protein samples were quantified using the bicinchoninic assay and standardized to $1 \mathrm{mg} / \mathrm{ml}$. Samples $(25 \mu \mathrm{l})$ were electrophoresced on $7.5 \%$ sodium dodecyl sulfide-polyacrylamide gel electrophoresis gels and thereafter transferred to nitrocellulose membranes. Membranes were blocked with 3\% bovine serum albumin (BSA) in Tris buffer saline (20 mM Tris- $\mathrm{HCl}(\mathrm{pH} 7.4)$, $500 \mathrm{mM} \mathrm{NaCl}$ and $0,01 \%$ Tween 20 (TBST)) for $1 \mathrm{~h}$, and incubated with primary antibody (p53, ab26; bax, ab5714; parp-1, ab110915; smac/DIABLO, ab110291 and $\beta$-actin, ab8226; $1: 1,000)$ in $1 \%$ BSA in TBST at $4^{\circ} \mathrm{C}$ overnight. Membranes were then washed thrice (10 ml TBST, $15 \mathrm{~min}$ ) and treated with horseradish peroxidase-conjugated secondary antibody (mouse, ab97046; 1:2,000) $(1 \mathrm{~h}, \mathrm{RT})$. Membranes were washed again 3 times (TBST, $15 \mathrm{~min}$ ) and immunoreactivity was detected by the LumiGLO ${ }^{\circledR}$ chemiluminescent substrate system (KPL) with the Uvitech Image Documentation System (UViTech Alliance 2.7). Protein bands were analyzed with the UViBand Advanced
Image Analysis software (UViTech v12.14). The results were expressed as mean relative band intensity (RBI).

\section{Statistical evaluation}

Statistical analyses were performed using GraphPad Prism version 5.00 software package $\left(\mathrm{GraphPad} \mathrm{PRISM}^{\circledR}\right)$. Data are expressed as mean \pm standard error of the mean (sem). Comparisons were made using unpaired $t$ tests. Statistical significance was set at 0.05 .

\section{Additional files}

Additional file 1: Figure S1. Extracellular staining-flow cytometry was used to evaluate the expression of CD95 (Fas receptor). Three replicates were done for both treated (B1-B3) and untreated (A1-A3) cells. AAAgNP significantly down regulated the expression of CD95 in A549 cells compared to the control $(2.8 \pm 0.58 \%$ vs. $5 \pm 0.44 \% ; p=0.0416$; $95 \% \mathrm{Cl}=0.13$ to 4.2 ).

Additional file 2: Figure S2. Levels of smac/DIABLO, a pro-apoptotic protein, were determined flow cytometrically using an intracellular staining assay. A significantly higher expression of smac/DIABLO was observed in A549 cells after treatment with AAAgNP (B1-B3) compared to untreated cells (A1-A3) $(29 \pm 0.32 \%$ vs. $18 \pm 0.66 \% ; p<0.0001 ; 95 \% \mathrm{Cl}=-13$ to -8.5$)$.

\section{Competing interests}

The authors declare that they have no competing interests.

\section{Authors' contributions}

The design of the study was proposed by AAC. RMG and KA were responsible for the synthesis and characterization of $A A_{A g N P}$. RG and AP carried out cell culture, subsequent experimental procedures as well as statistical analyses. The manuscript was drafted by RG, AP and AAC. All authors read and approved the final manuscript.

\section{Acknowledgements}

Mr R Govender acknowledges funding for this study from the College of Health Sciences, University of KwaZulu-Natal and a scholarship from the National Research Foundation (SA).

\section{Author details}

${ }^{1}$ Discipline of Medical Biochemistry, School of Laboratory Medicine and Medical Sciences, University of KwaZulu-Natal, Private Bag 7, Congella, Durban 4013, South Africa. ${ }^{2}$ Department of Chemistry, Faculty of Applied Sciences, Durban University of Technology, Durban 4001, South Africa.

Received: 14 November 2012 Accepted: 30 January 2013 Published: 18 February 2013

\section{References}

1. Bello B, Fadahun O, Kielkowski D, Nelson G: Trends in lung cancer mortality in South Africa: 1995-2006. BMC Public Health 2011, 11:209.

2. Siemiatycki J, Richardson L, Straif K, Latreille B, Lakhani R, Campbell S, Rousseau MC, Boffetta P: Listing occupational carcinogens. Environ Health Perspect 2004, 112(15):1447-59.

3. Driscoll T, Nelson DI, Steenland K, Leigh J, Concha-Barrientos M, Fingerhut M, Pruss-Ustun A: The global burden of disease due to occupational carcinogens. Am J Ind Med 2005, 48(6):419-31.

4. Long JL, Engels EA, Moore RD, Gebo KA: Incidence and outcomes of malignancy in the HAART era in an urban cohort of HIV-infected individuals. AIDS 2008, 22(4):489-96.

5. Su J, Zhang J, Liu L, Huang Y, Mason RP: Exploring feasibility of multicolored CdTe quantum dots for in vitro and in vivo fluorescent imaging. J Nanosci Nanotechnol 2008, 8(3):1174-7.

6. Moaddab S, Ahari H, Shahbazzadeh D, Motallebi AA, Anvar AA, Rahman-Nya J, Shokrgozar MR: Toxicity Study of Nanosilver $\left(\right.$ Nanocid ${ }^{\circledR}$ ) on Osteoblast Cancer Cell Line. Int. Nano Lett 2011, 1(2):6. 
7. Arora S, Jain J, Rajwade JM, Paknikar KM: Cellular responses induced by silver nanoparticles: In vitro studies. Toxicol Lett 2008, 179(2):93-100.

8. Hansen SF, Michelson ES, Kamper A, Borling P, Stuer-Lauridsen F, Baun A: Categorization framework to aid exposure assessment of nanomaterials in consumer products. Ecotoxicology 2008, 17(5):438-47.

9. Madhumathi K, Sudheesh Kumar PT, Abhilash S, Sreeja V, Tamura H, Manzoor K, Nair SV, Jayakumar R: Development of novel chitin/nanosilver composite scaffolds for wound dressing applications. J Mater Sci Mater Med 2010, 21(2):807-813.

10. Bhattacharya R, Mukherjee P: Biological properties of "naked" metal nanoparticles. Adv Drug Deliv Rev 2008, 60(11):1289-306.

11. Kalishwaralal K, Barathmanikanth S, Pandian SR, Deepak V, Gurunathan S: Silver nano - a trove for retinal therapies. J Control Release 2010, 145(2):76-90.

12. Lara HH, Ayala-Nunez NV, Ixtepan-Turrent L, Rodriguez-Padilla C: Mode of antiviral action of silver nanoparticles against HIV-1. J Nanobiotechnology 2010, 8:1.

13. Lu L, Sun RW, Chen R, Hui CK, Ho CM, Luk JM, Lau GK, Che CM: Silver nanoparticles inhibit hepatitis B virus replication. Antivir Ther 2008 , 13(2):253-62.

14. Baram-Pinto D, Shukla S, Perkas N, Gedanken A, Sarid R: Inhibition of herpes simplex virus type 1 infection by silver nanoparticles capped with mercaptoethane sulfonate. Bioconjug Chem 2009, 20(8):1497-502.

15. Xu L, Li X, Takemura T, Hanagata N, Wu G, Lee Chou L: Genotoxicity and molecular response of silver nanoparticle (NP)-based hydrogel. Journal of Nanobiotechnology 2012, 10(16):1-11.

16. Ghosh M, Manivannan J Sinha S, Chakraborty A, Mallick SK, Bandyopadhyay $M$, Mukherjee $A$ : In vitro and in vivo genotoxicity of silver nanoparticles. Mutation Research/Genetic Toxicology and Environmental Mutagenesis 2012, 749:60-69.

17. Vaidyanathan R, Kalishwaralal K, Gopalram S, Gurunathan S: Nanosilver-the burgeoning therapeutic molecule and its green synthesis. Biotechnol Adv 2009, 27(6):924-37.

18. Foldbjerg R, Dang DA, Autrup H: Cytotoxicity and genotoxicity of silver nanoparticles in the human lung cancer cell line, A549. Arch Toxicol 2011, 85(7):743-50.

19. Lacaille-Dubois MA, Wagner $\mathrm{H}$ : Bioactive saponins from plants: An update. In Studies in Natural Products Chemistry. Edited by Attaur R. The Netherlands: Elsevier Science B. V.; 2000:633-687.

20. Haddad M, Laurens V, Lacaille-Dubois MA: Induction of apoptosis in a leukemia cell line by triterpene saponins from Albizia adianthifolia. Bioorg Med Chem 2004, 12(17):4725-34

21. Mujoo K, Haridas V, Hoffmann JJ, Wachter GA, Hutter LK, Lu Y, Blake ME, Jayatilake GS, Bailey D, Mills GB, Gutterman JU: Triterpenoid saponins from Acacia victoriae (Bentham) decrease tumor cell proliferation and induce apoptosis. Cancer Res 2001, 61(14):5486-90.

22. Francis $G$, Kerem Z, Makkar HP, Becker K: The biological action of saponins in animal systems: a review. Br J Nutr 2002, 88(6):587-605.

23. Sahu SC, Casciano DA: Nanotoxicity, from In vivo and In vitro Models to Health Risks. USA: John Wiley and Sons, Ltd; 2009:609.

24. Chairuangkitti $P$, Lawanprasert $S$, Roytrakul S, Aueviriyavit S, Phummiratch D, Kulthong K, Chanvorachote P, Maniratanachote R: Silver nanoparticles induce toxicity in A549 cells via ROS-dependent and ROS-independent pathways. Toxicology in Vitro 2013, 27:330-338.

25. Fischer U, Schulze-Osthoff K: New approaches and therapeutics targeting apoptosis in disease. Pharmacol Rev 2005, 57(2):187-215

26. Chai J, Du C, Wu JW, Kyin S, Wang X, Shi Y: Structural and biochemical basis of apoptotic activation by Smac/DIABLO. Nature 2000, 406(6798):855-62.

27. Kasibhatla S, Tseng B: Why target apoptosis in cancer treatment? $\mathrm{Mol}$ Cancer Ther 2003, 2(6):573-80.

28. Shall S, de Murcia G: Poly(ADP-ribose) polymerase-1: what have we learned from the deficient mouse model? Mutat Res 2000, 460(1):1-15.

29. Hirsch T, Marzo I, Kroemer G: Role of the mitochondrial permeability transition pore in apoptosis. Biosci Rep 1997, 17(1):67-76

30. Wang $X$ : The expanding role of mitochondria in apoptosis. Genes Dev 2001, 15(22):2922-33.

31. Navarro E, Piccapietra F, Wagner B, Marconi F, Kaegi R, Odzak N, Sigg L, Behra R: Toxicity of silver nanoparticles to Chlamydomonas reinhardtii. Environ Sci Technol 2008, 42(23):8959-64.

32. Foldbjerg R, Olesen P, Hougaard M, Dang DA, Hoffmann HJ, Autrup H: PVPcoated silver nanoparticles and silver ions induce reactive oxygen species, apoptosis and necrosis in THP-1 monocytes. Toxicol Lett 2009, 190(2):156-62

33. Ueda S, Masutani H, Nakamura H, Tanaka T, Ueno M, Yodoi J: Redox control of cell death. Antioxid Redox Signal 2002, 4(3):405-14.

34. Hostettmann K, Martson A: Saponins. Cambridge: Cambridge University Press; 1995.

35. Derfus AM, Chan WCW, Bhatia SN: Intracellular Delivery of Quantum Dots for Live Cell Labeling and Organelle Tracking. Adv Mater 2004, 16(12):961-966.

36. Xia T, Kovochich M, Brant J, Hotze M, Sempf J, Oberley T, Sioutas C, Yeh Jl, Wiesner MR, Nel AE: Comparison of the abilities of ambient and manufactured nanoparticles to induce cellular toxicity according to an oxidative stress paradigm. Nano Lett 2006, 6(8):1794-807.

37. Carlson C, Hussain SM, Schrand AM, Braydich-Stolle LK, Hess KL, Jones RL, Schlager JJ: Unique cellular interaction of silver nanoparticles: sizedependent generation of reactive oxygen species. J Phys Chem B 2008, 112(43):13608-19.

38. Xia T, Kovochich M, Liong M, Madler L, Gilbert B, Shi H, Yeh Jl, Zink Jl, Nel $A E$ : Comparison of the mechanism of toxicity of zinc oxide and cerium oxide nanoparticles based on dissolution and oxidative stress properties. ACS Nano 2008, 2(10):2121-34.

39. Miyashita T, Krajewski S, Krajewska M, Wang HG, Lin HK, Liebermann DA, Hoffman B, Reed JC: Tumor suppressor p53 is a regulator of bcl-2 and bax gene expression in vitro and in vivo. Oncogene 1994, 9(6):1799-805.

40. MacLachlan TK, El-Deiry WS: Apoptotic threshold is lowered by p53 transactivation of caspase-6. Proc Natl Acad Sci U S A 2002, 99(14):9492-7.

41. Hwang PM, Bunz F, YU J, Rago C, Chan TA, Murphy MP, Kelso GF, Smith RA, Kinzler KW, Vogelstein B: Ferredoxin reductase affects p53-dependent, 5fluorouracil-induced apoptosis in colorectal cancer cells. Nat Med 2001, 7(10):1111-7.

42. Gengan RM, Anand K, Phulukdaree A, Chuturgoon A: A549 lung cell activity of biosynthesized silver nanoparticles using Albizia adianthifolia leaf. Colloids and Sufaces B: Biointerfaces 2013, doi:10.1016/j. colsurfb.2012.12.044

doi:10.1186/1477-3155-11-5

Cite this article as: Govender et al: Silver nanoparticles of Albizia adianthifolia: the induction of apoptosis in human lung carcinoma cell line. Journal of Nanobiotechnology 2013 11:5.

\section{Submit your next manuscript to BioMed Central and take full advantage of:}

- Convenient online submission

- Thorough peer review

- No space constraints or color figure charges

- Immediate publication on acceptance

- Inclusion in PubMed, CAS, Scopus and Google Scholar

- Research which is freely available for redistribution 